\title{
近世小保・榎津における町並みの成立と展開 FORMATION AND DEVELOPMENT OF THE KOBO AND ENOKIDU URBAN SPACE IN THE EARLY MODERN TIMES PERIOD
}

\author{
安高 尚 毅*
}

Naoki ATAKA

\begin{abstract}
This study takes up Kobo and Enokidu in Okawa-shi, Fukuoka. These cities are good examples that understand a city space change from the medieval times to early modern times. A city restored map is created with the land-register map of Meiji. And that city is restored retroactively. Formation and deployment of the city of Kobo and Enokidu are clarified by this change process, and an urban form, the name of a place and the formation age of temples and shrines.
\end{abstract}

Keywords : Rural Districts Town, Early Modern,Restoration 在方町, 近世, 復原

序

これまで近世在方町に関する研究は、様々な地域の研究がある朔 1)。近年、これらの研究により、当時の都市空間の実像が明らかになっ てきた。だが、在方町の中世から近世にかけての変容を明らかにし ているものは史料的制約もあり、研究蓄積は少ない。近年、在方町 は、宮本雅明の論考 ${ }^{1)}$ により、近代社会を拓いた在方町として位置 付けがなされている。また、中世から近世への都市空間の変容も管 理交易から市場交易の展開をもとに宮本雅明により解明が進んでい る。本稿の小保・榎津も、その論考の中で取り上げられているが注2)、 その詳細な分析は報告されていない。

よって、本稿は中近世移行期の在方町の空間変容の推定できる福 岡県大川市小保・榎津を事例として取り上げ、その成立と展開を明 らかにし、近世在方町の空間構造の特質について明らかとするとと もに近世中期の都市復原図を基として中世の古文書・寺社起源・都 市形態を駆使しつつ、中世に逆った復原考察を行い、都市の成立過 程の仮説を提示したい。

筑後川河口に位置する大川市は、花宗川に沿った小保・榎津と筑 後川に沿った住吉・若津の四つの伝統的町並夕から成る。藩政時代 において、若津と榎津は久留米藩に属し、住吉と小保は柳川藩に属 し、それぞれ城下町久留米と城下町柳川の外港として機能した。小 保と榎津は中世に成立起源が遡ると見られ、若津と住吉は近世中期 に新たに町建てされた港町であり、これら多様な性格を備える四つ
の港町は都市史上注目すべき存在で、これらを比較することにより 多くの知見が得られると考えられる。

\section{1. 小保・榎津の町並みの基本構造}

1-1. 地籍図による明治期都市復原図の作成

屋敷割の復原図を作成する目的はそこから形態的な特徵を読み取 り、都市の形成過程を推察するためである。小保・榎津の復原図を 作成するにあたって、基となる史料は、明治 20 年代の「明治の地

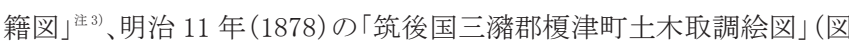
1）洋4)、明治 11 年以降明治 21 年以内（1878～1888）の「筑後国三 潴郡榎津町之図」(図 2) 洋5)、明治 11 年（1878）の「筑後国三㵔郡 小保町土木取調図」(図 3) 注6) である。小保・榎津の町並みが展開 していた場所は図 1、図 2、図 3 より判明する。榎津の小字には「柳 町」「薮町」「出来町」「向町」「北浜町」「長町」「城町」「浦町」「船 倉」「横町」「庄分町」「本町」「水入町」「津村町」「津村口（一部）」 があり、小保の小字には、「上町市場浦」「中船津」「新町浦」があ ることが知られる。これらの情報を基に、明治の地割復原図を作成 することができる。復原図は明治期の地籍図を 2500 分の 1 の都市 計画図に照合して作成した(図 4)。また、復原図を作成するにあたっ て、榎津の柳町と津村口は、町が連続していないことより除いた。 以下、これを基本資料とし、空間に即した小保・榎津の歴史を考察 していく。

\footnotetext{
* 島根大学大学院総合理工学研究科 助教 · 博士 (芸術工学)
}

Assistant Prof., Interdisciplinary Graduate School of Science \& Engineering, Shimane University, Dr. Des. 


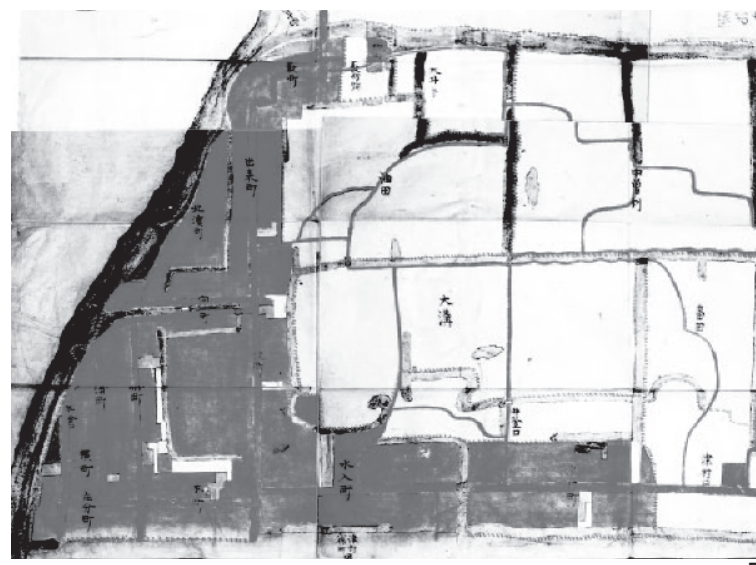

図 1 筑後国三㴚郡榎津町土木取調絵図（明治 11 年）（部分）

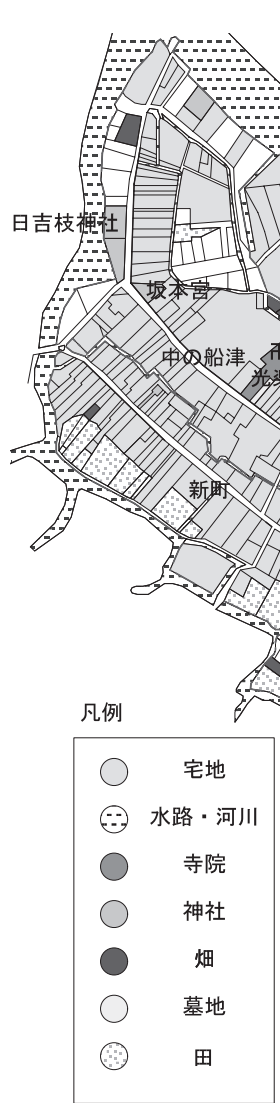

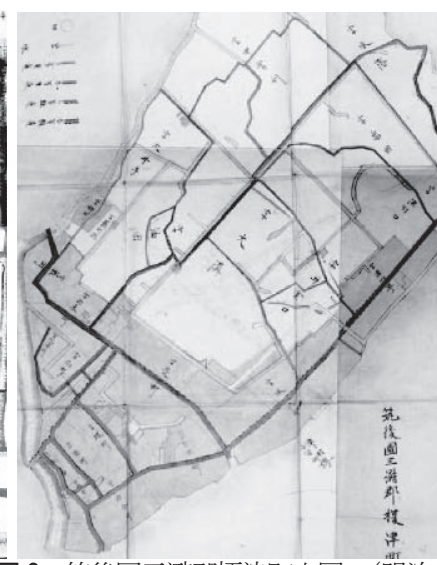

図 2 筑後国三潴郡榎津町之図（明治 11 年以降明治 21 年以内）(部分）

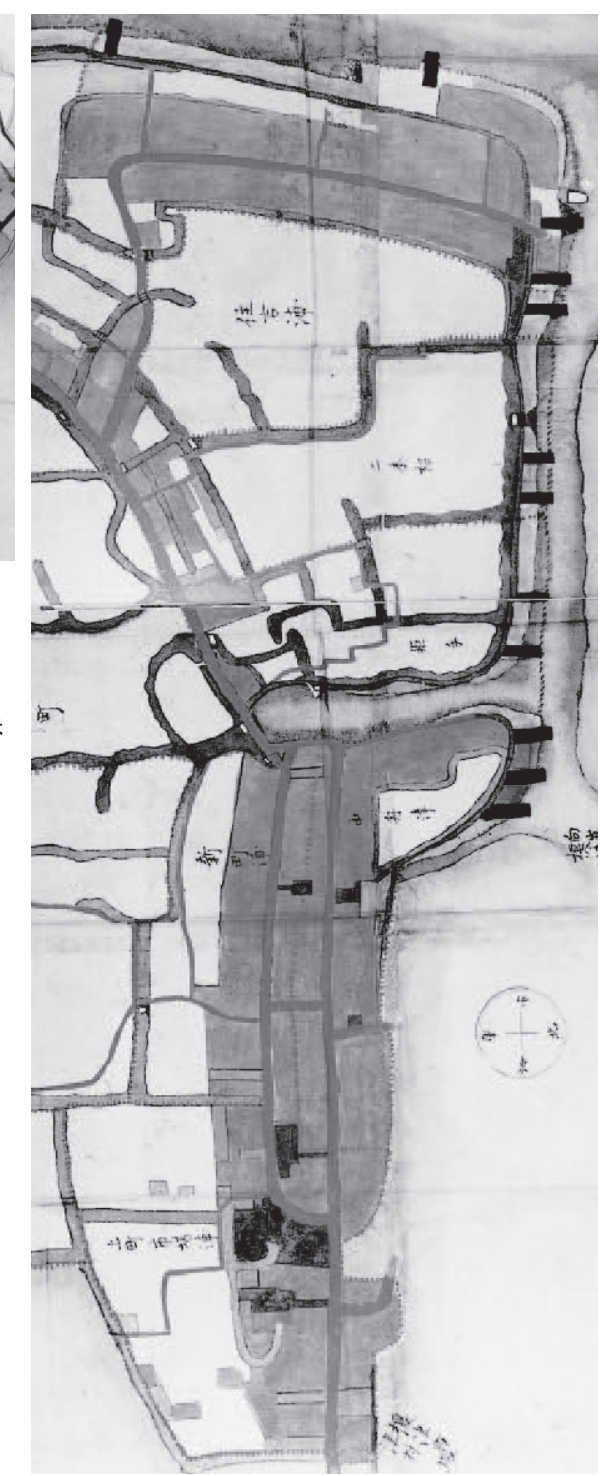

図 3 筑後国三㴚郡小保町土木取調図（明治 11 年）（部分）

辻が結節点となり、そこから花宗川に向かっ て小保の上町市場・中の船津（後に船津町と 仲町）、裏手に新町、北東側に並行して、榎 津の本町・庄分町、札の辻から柳川方面には 榎津の水入町・津村町、久留米方面には榎津 の長町・出来町・藪町が連なり、その裏手に

図 4 小保・榎津明治期都市復原図

\section{1-2. 町並みの空間構成}

明治期都市復原図の作成過程において、現在の都市計画図と明治 期の地籍図は部分的な道路の変化を除けば、一応の合致をみること ができ、明治の地籍図が信用のおける資料であると共に、現在の小 保・榎津の町並みが少なくとも町割・地割に関して幕末ないし明治 初年の様相をかなりよく残していることが確認できた。この地籍図 には近世期に形成された町並みの到達点が描かれていると考えるこ とが出来よう。これに依拠しつつ小保・榎津の町並みの空間構成を 眺める。

伝統的町並みは東方の柳川に向かう街道に繋がる道筋と、北方の 久留米に向かう街道に繫がる道筋を主軸として広がる。両者は札の
榎津の城町・浦町・横町が広がり、花宗川から入り込む江湖を挟ん で向町が広がる。町筋の背割りには水路が通される。これら水路 によって小保と榎津、さらに諸町が画され、河川と江湖によって 周辺地域から町並みは画される。久留米側では藪町と出来町およ び出来町と向町、柳川側では津村町と水入町の境に矩折れが設け られる。地割は間口が狭く奥行きの長い短冊状の地割が多くを占 める。

\section{1-3. 住吉・若津の都市復原図の作成とその特徵}

次に、中世に成立起源が遡ると見られる小保・榎津と比較する ため、下流に近世中期に新たに町建てされた港町若津と住吉の町 並みの特徵を把握しておきたい。住吉・若津の町並夕を復原考察 するにあたって、基となる絵図及び資史料は、明治 20 年代の「明 


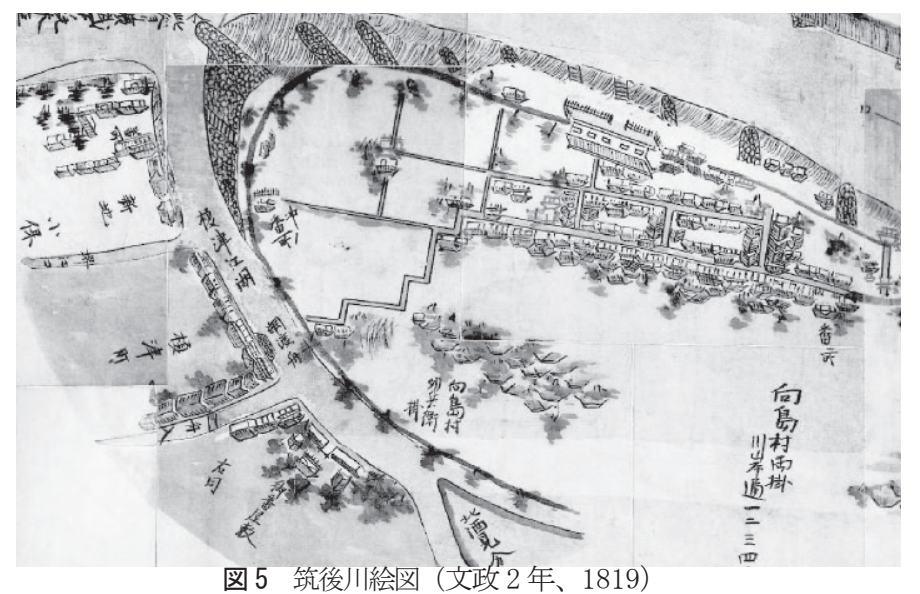

治の地籍図」注7)、明治 11 年（1878）の「筑後国三溷郡小保町図」 (図 3)、文政 2 年（1819）の「筑後川絵図」(図 5) 注8)、年代不詳の 「住吉宮旧記写」 ${ }^{3 * 99}$ 、『大川市誌』2) である。住吉は「住吉宮旧記写 」により町建て時の様子が、若津は「筑後川絵図」により街路網と 町並みの展開していた場所、『大川市誌』により、町並みが展開し ていた小字が「北一の割」「北二の割」「南一の割」「南二の割」「三 の割」「四の割」であることがわかる。これにより住吉・若津の都 市復原図を作成することが出来る。復原図は明治期の地籍図を現状 2500 分の 1 の都市計画図に照合して作成した（図6)。

安永 4 年 (1775) に計画的町建てのされた住吉は、町全体は長方 形の形態をしており、地尻が直線的な水路で決定され、「住吉宮旧 記写」の記載通り計画的な町割である。街路は町を十字に走り、間 口が面する南北方向の街路は長方形の町の中心に通され、東西方向 の街路も町の中心に通される。この街路に面して宅地が整然と並び 両側町を形成する。この街路の長さ及び地割の奥行きを子細に眺め ると、南北方向の街路の北側が $110 \mathrm{~m}$ 、南側も $110 \mathrm{~m}$ 、地割の奥行き は西側が 50m、東側が $54 \mathrm{~m}$ と左右対称の形態を示し、間口の広さも 約 4 間とほぼ均質と言え、計画的な町割であることが数值からも読 み取れる。

宝暦元年（1751）に開港される若津は、町全体は長方形の形態を しており、地尻は水路で決定されている。整然とした屋敷割で直線 的な街路が縦横に通され、両側町を形成し、計画的な様相を呈する。 古老の話によると「若津の町は大体間口四間、奥行き二十間に区画 され、街路の幅が広いのは（5.5メートル）、昔、船の太網を道路 で巻いていたからです。とある注10)。これを念頭において地割の奥 行きを見ていくとほとんどが 23 間でこの話と合致する。

以上、住吉・若津の町割及び地割は、間口が均質で、地尻は直線
的な水路で決定される形態と言え、近世に計画的に町建てされた町 並みの典型的例として捉えられる。住吉の地割の計画寸法は間口 4 間・奥行き 27 間、若津の地割の計画寸法は間口 4 間・奥行き 23 間 で、間口は共通するものの奥行きを 4 間ほど違える。

\section{1-4. 小保・榎津の町並みの形態的特徵}

小保・榎津の街路形態は、緩やかに曲がっているものと直線的な ものとに大別される。緩やかに曲がっているものは小保の上町市場・ 中の船津・新町、榎津の本町 · 庄分町 - 浦町 - 船倉 - 長町、直線的 なものは榎津の水入町 - 津村町 $\cdot$ 城町 $\cdot$ 横町 $\cdot$ 向町 $\cdot$ 出来町 $\cdot$ 薮町 である。

地割は、間口・奥行きとも不均質な地割を呈する町と、間口・奥 行ともに均質な町の二つに大別できる。前者に当たるのは小保の上 町市場・中の船津、榎津の本町・庄分町・水入町で、後者に当たる

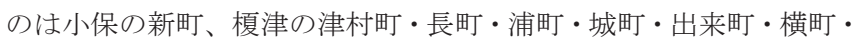
向町・藪町である。両者ともに宅地の奥行が $9 \sim 30$ 間と浅い点も 目を引く。

街路と地割の配置関係は、ほとんどの町が両側町である。例外的 に小保の上町市場の一部、中の船津の一部は片側町となる。また、 榎津の向町は明治 11 年の「筑後国三㴚郡榎津町絵図」(図 1) から 現在のような 2 本の両側町を形成せず、水路が埋め立てられていな いため、水路を隔て、北側・南側に別れ、2 本の片側町として成立 していたことが知られる。榎津の北浜町は線形の空間を形成せず、 敷地が短冊状ではない。

地尻は、水路によって決定されるか、お互いの地尻が錯綜しなが ら接するかであるが、どちらの場合も形態は直線的なものとそうで ないものとがある。直線的でないものは、小保の上町市場・中の船 津・新町、榎津の本町・長町・庄分町で、直線的なものは、榎津の 津村町 - 薮町 - 出来町 - 横町 $\cdot$ 浦町 $\cdot$ 北浜町で、片側が直線的なも のは榎津の水入町・城町・向町である。

以上、小保・榎津の町並みは地割が不均質で街路も直線的でない 場所、地割が均質で街路が直線的である場所など混在した町並みの 様相を呈し、不統一な空間を形成していたことが把握されよう。

\section{2. 近世中期小保・榎津の町並み復原}

\section{2-1. 小保 ·榎津の近世中期都市復原図の作成}

近世中期における榎津の町並みを窥い知孔る史料として、「米府 記事略之巻 5」 (11) 3)、「久留米領郡中品々寄」注 12) 4)、『石原家記』5)、「啓 忘録抜粋」注13) 6) がある。

「米府紀事略之巻 5」（正保 3 年、1647）には「家数四百十二軒」 とあり、「久留米領郡中品々寄」（元禄 8 年、1695）には「長五丁

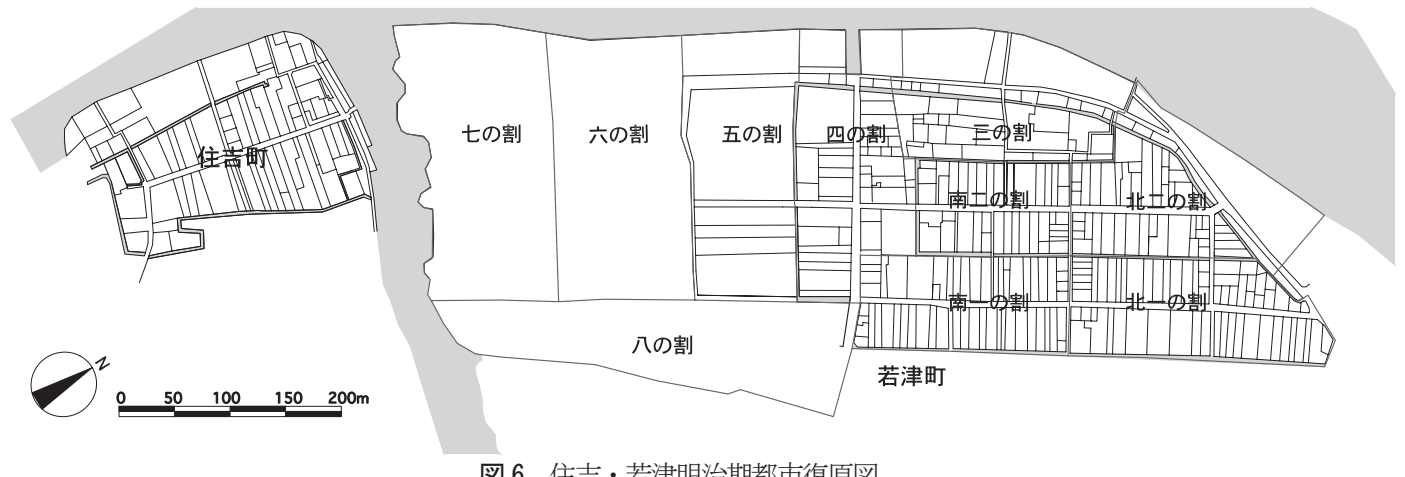

図 6 住吉・若津明治期都市復原図 
三十三間榎津町」（333 間、633m）とあり、『石原家記』（宝永 3 年、 1707）には「一榎津町䆞数四百六十武間、但丁数十六町三十六間、 人数式千百四十一人、馬数二十五㱜。一同町船数武百廿石但百十九 艘二十端より弐十櫓船迄、往来御札申受候。八十一艘八艀札、八艘 八貝取船、武艘は渡船。」（996 間 $1.9 \mathrm{~km} ）$ とあり、「啓忘録抜粋」（宝 永 7 年以前、1710)には「四百拾八軒但丁数拾三町五拾間榎津町」(830 間 $1.6 \mathrm{~km})$ とある。

この中で、「啓忘録抜粋」（宝永 7 年以前）は家数 418、町長さ 13 町 50 間、『石原家記』(宝永 3 年) は䆞数 462、町長さ 16 町 36 間 と似た值を示す。さらに、「米府紀事略之巻 $5 」$ (正保 3 年) は家数 412 軒とあり、「啓忘録抜粋」『石原家記』の值と近い。よって、こ れら 3 つの史料は信が置けると考えられる。また、「啓忘録抜粋」は、 内容中に見られる最も新しい年紀が宝永 7 年で、宝永 7 年以降に刊 行されたものとされるが、多くの記述内容で宝永 7 年以前の年紀が 窥え、この榎津の記述に年紀は記載されない。よって、いつの時期 を表しているかについては疑問が残ろう。『石原家記』「米府紀事略 之巻 $5 」$ と照合すると宝永 7 年以前の状態を記している可能性は高 い。また、「久留米領郡中品々寄」（元禄 8 年）は他の史料と大きく 異なっており、記述内容に疑いがもたれる。

以上より、「米府紀事略之巻 5」と『石原家記』が年紀が 明らかであり信用がおけよう。ことに年紀が確定的で家数と 町長さの両方がわかる『石原家記』の記述が重要といえよう。

以上より、小保・榎津明治期都市復原図の榎津の町長さは 24 町 28 間で、宝永 3 年から明治にかけて 472 間伸びたこと になろう。この部分はどの場所に当たるのであろうか。

住吉・若津の都市復原図の分析より近世期の計画的に町建 てのされた町は街路が直線的で地尻も直線的な水路により決 定され間口が均質である形態を示すことがわかった。472 間 の場所は近世後期に建設されたと考えられるから、地割・町 割がこのような形態になっている場所がそれに当たると予想 されよう。

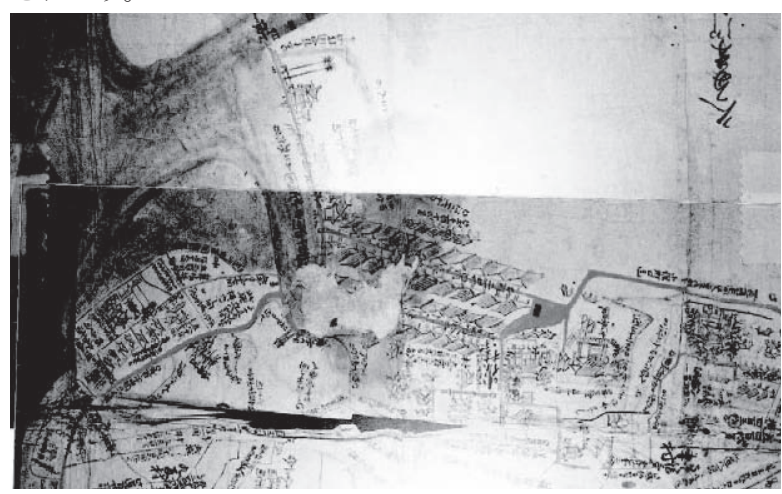

図 7 三渚郡蒲池与絵図（正保 2 年）

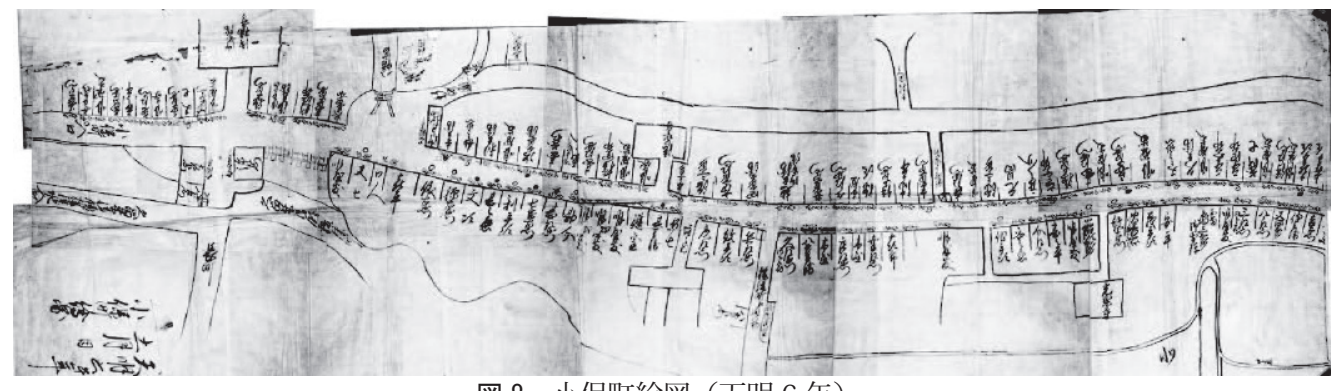

図 8 小保町絵図（天明 6 年）
町の拡大が計画的にされたとすれば字ごとに拡大したと考えるの が一般的であろう。

住吉・若津で見られるような計画的な要素を持っている近世期の 町建ての形態、いわゆる間口が均質で直線的なものは、小字でいう と出来町、津村町、浦町、横町、薮町、向町北側である。これらは 住吉・若津の形態に酷似しているということで、近世中期から後期 にかけて計画的に町建てされた可能性が高いと言えよう。他のもの は住吉・若津の形態に類似しないことより、中世起源の可能性があ ると言えようか。

榎津を通る肥後街道の入口である津村町、薮町は、町の最も外側 にあることから、町がある時期に拡大したとすれば、津村町、薮町 を拡大したと考えるのが自然であろう。

寺社起源も考慮しておく必要がある。近世期に寺社起源が求めら れるのは北浜町の水天宮 (1708)、津村町の多福寺（1628）である。 次にこれらのことを射程に置き、町の長さを測っていく。

町の長さは、水入町が 193 間、本町が 98 間、庄分町が 140 間、 長町が 124 間、城町が 124 間、船倉が 61 間、横町が 34 間、浦町が 111 間、出来町が 94 間、藪町が 89 間、津村町が 121 間、向町が 115 間、 北浜町が 193 間である（総町数は 24 町 28 間)。街道の入口にあた

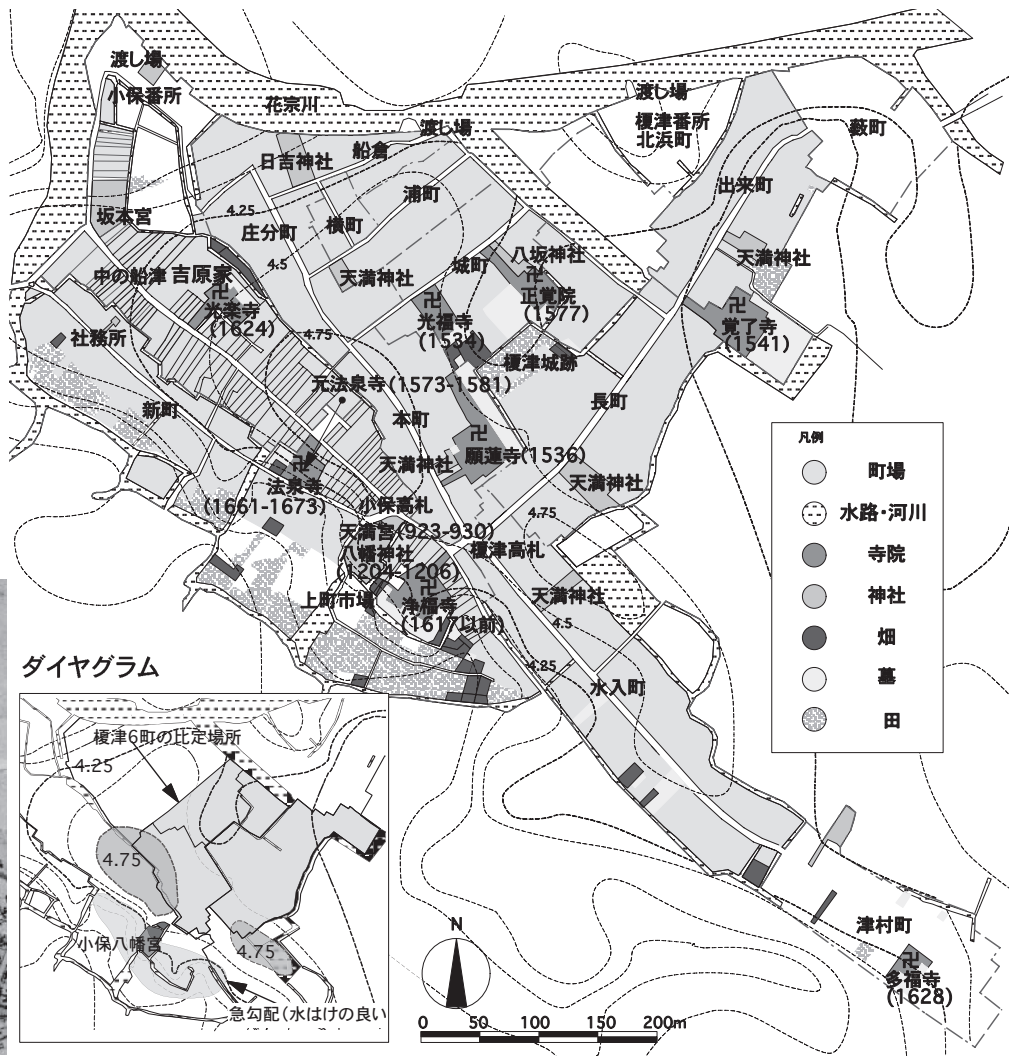

図 10 小保・榎津近世中期復原図

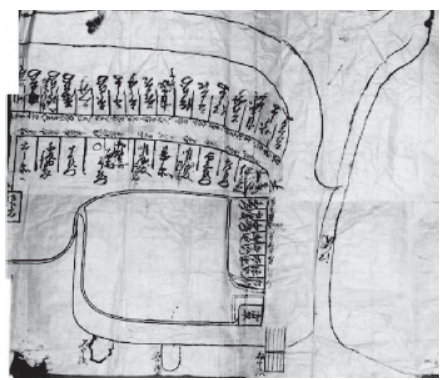

図 9 小保町絵図（年代不詳） 
り町の最も外側に位置し、間口が均質で直線的な地尻を有する津 村町（121 間) ・薮町（89 間）と、町の周縁であり藩政期屋敷地で 1708 年に成立した水天宮の存在する北浜町（193 間）、次に外側に あり数字のつじつまが合い間口が均質で直線的な地尻を有する向町 の北側（69 間）を除くと、ちょうど 16 町 36 間となり『石原家記』 と合致する。また、津村町・薮町・向町の北側は地割の計画寸法が 間口 4.7 間・奥行き 17 間を示し、若津の計画寸法とは異なるもの の ${ }^{\text {i: 14) }} 3$ 者は共通する。この寸法は他の場所とは共通性を見出せな いことも傍証となろう。よって、明治の復原図を下敷きに榎津の近 世中期都市復原図がつくられる。

小保は「三洦郡蒲池与絵図」（正保 2 年、1645）（図 7) 注 15) に既 に明治の復原図と同じ範囲に町並みが描かれているため、町の拡 大はなかったと考えられる。また、「小保町絵図」(天明 6 年 11 月、 1786）（図 8） 注16)、「小保町絵図」（年代不詳、天明 6 年以降）（図 9） 注 17) に上町市場、中の船津に間口の広さが書かれており、明治の復 原図を下敷きに地割レベルで復原することができる。さらに、図 8 より小保の御高札場の位置が、宝暦 9 年（1759）2 月の「境図」(図 11） 洋18) により榎津の御高札場の位置が知られる。

以上より、小保・榎津の近世中期の町並みの範囲が推定され、近 世中期復原図が作成される（図 10）。

\section{2-2. 小保 ·榎津の近世中期の空間構成}

近世中期復原図（図 10）によって町並みの範囲を平面的に捉え ることが出来た。この図 10 により近世中期における町並みの空間 構成上の特質をおおよそ把握することが出来る。小保の町並みは安 定した空間構成を成立させ、榎津の町並みは東側を枰形で画され、 南側と西側を江湖、北西側を花宗川、北側を江湖で画された中に、 近世中期の町並みは広がり、北側に出来町が張り出していたことに なろう。都市形態の特徴として、小保は格差のある間口、小保・榎 津ともに自然発生的な道と思われるカーブを描く街路および地尻を 持つことで、住吉・若津の近世中期に計画的に町建てされた町と形 態が著しく異なることが指摘される。

このような平面上にどのような町並みが展開していたのであろう か。絵図を駆使することにより、その様相を立体的に推察していき たい。なお、絵図史料は小保を描いたものが多いため、小保を中心 とした町並みの様相を考察していくこととなる。

小保の町並みが具体的に描かれているものの中で、最も古い絵図
は正保 2 年（1645）の「三㴚郡蒲池与絵図」（図 7）である。一部 久損が見られるものの、入り江や道筋の他、寺社・民家を描く。子 細に眺めると浄福寺、八幡神社が描かれ、その前に広場の様な空間 が存在し、紫の四角で御高札場が描かれる。また、浄福寺東の札の 辻付近に後の絵図には描かれない「御茶屋」の文字が見える。柳川 藩が近世前期にここに御茶屋を設置したということは、小保の町が 重要であると認識するとともに、小保の町並みの中でも小保八幡神 社周辺が町の要であると考えていたと推察される。小保本通りの上 町市場、中の船津には妻入りの町家が両側に隙間なく並んでおり、 新町も同様に並んでいる。坂本宮からは片側だけとなる。通りが花 宗川に突き当たり、そこに渡し場が 3 つ設けられ、その手前に番所 が見え、堤が花宗川と小保の町を隔て、それが入り江と渡し場を取 り囲む。町並みは草莫きか瓦莫きかは判断できないが、寺社と町家 では、寺社の屋根に鬼瓦のようなものをのせており、描かれ方に差 がある。町並みを構成する町家は妻入で描かれる。

次に町並みが描かれているのが、宝暦 9 年 (1759) 2 月の「境図」 (図 11) で、町並みの様子は「三㵔郡蒲池与絵図」(正保 2 年) (図 7) とあまり変化はないが、町並みは平入りにて描かれ、図 7 と矛盾す る。その他、榎津と小保の藩境の石が描かれ、社寺は法泉寺・天神森・ 光楽寺が描かれる。また、土塁が入り江と渡し場を取り囲むことが より詳しく窥え、光楽寺の裏まで続いていることが把握される。こ の藩境の石は『大川市誌』の古老の話によると、「馬継場で藩境の 石には馬をつないでいたらしい。とある洋19)。町並みは草莫きか瓦 蕞きかも判断できないが、『大川市誌』の古老の話によると、「小保 町の家々は大正頃までほとんどの家が平屋建てで草草きであった」 という注20)。このことから町並みは、草莫きの町家が連続して形成 していたと考えられよう。

天明 6 年 (1786) 11月の「小保町絵図」(図 8) からは、上町市場・ 中の船津の屋敷間口の広さがわかる。

間口の広さの分布は、 2 間が $27 、 2$ 間半が $29 、 3$ 間が $21 、 3$ 間半 が 10、4 間が $4 、 4$ 間半が $4 、 5$ 間が 3、5 間半が $2 、 6$ 間が $4 、 6$ 間 半が $1 、 8$ 間が $1 、 9$ 間が $4 、 11$ 間が 1 である。 $2 \sim 11$ と間口の規 模が様々で、狭い間口が大半を占めていることが特徴的である。ち なみに年代不詳の「小保町絵図」（図 9）は 9 尺が 3、2 間が 12、2 間半が $7 、 3$ 間が $4 、 4$ 間が $4 、 6$ 間が $1 、 8$ 間半が 3、12 間半が 1 で ある。こちらからも間口規模に隔たりがあることが読み取れる。よっ

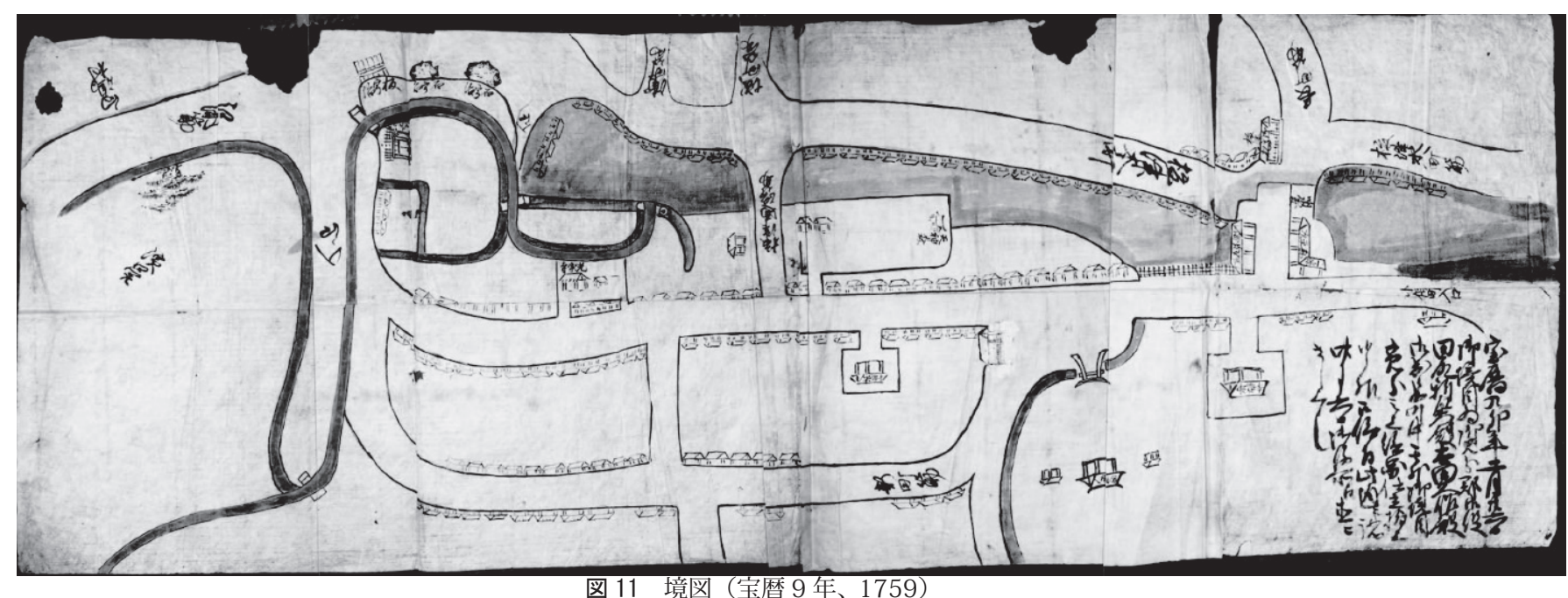


て、小保の町並みは、間口の分布は 2 間半のものが最も多く、間口 2 間半に建築される町家が町並みの大部分を形成していたと考えら れる。

以上より、小保の町並みは小型町家がずらりと並ぶ町並みに中・ 大型町家が所々に現れる格差ある町並みを形成していたようだ。ま た、間口が 2 間の敷地が $3 \sim 4$ 連続していることも特徵としてあげ られる。

一方、「筑後川絵図」（文政 2 年、1819）（図 5）は若津の町並夕 が詳しく描かれ、小保・榎津の近世期の町並みを推察するのに参考 になり大変貴重な絵図である。

図 5 の若津の町家は妻入りと平入りに分けて描かれ、ほとんどが 平入り草莫き平屋建てである。それ以外に描かれるものとして妻入 り入母屋瓦莫き二階建てのものと平入り切り妻瓦莫き平屋建てのも のがある。僅かではあるが榎津の町並みも描かれている。榎津は舟 入りと榎津江湖が描かれ、御番屋敷が描かれる。舟入りからの位置 関係から北浜町と考えられる。舟入りの入口には二階建て町家が描 かれる。若津は榎津の隣町で、同じ藩に属することから、榎津の町 並夕も草莫平屋建て町家の並ぶ町並みに妻入り入母屋瓦莫き二階建 て・平入り切り妻瓦莫き平屋建ての町家が点在する景観を形成して いたと推察される。これは小保の町並み景観の考察とも相通じ、図 11 ・図 8 ・図 9 が実際を表していると考えられようか。

以上、絵図史料を用い、小保・榎津の近世中期の町並みが非常に 変化に富み、通りに沿って平入り草莫き町家が連続して町並みを形 成する景観に、中・大型町家が所々に現れる格差ある町並みを形成 していたというおおよその全体像を提示することができた。

\section{2-3. 小保・榎津の社会構成}

藩政時代、小保・榎津はどのような支配体制の中に属していたの であろうか。

小保町は柳川藩蒲池組に属し、別当を置く。別当は代々吉原家が 世襲し、嘉永 4 年より大庄屋も務めるようになる。榎津町は久留米 藩平野組に属し、寛文 12 年までは大庄屋を置き、それ以降は別当 を置く。榎津の別当は大庄屋と同じ扱いを受けていた。このような 支配体制のもと、それぞれ港町として成立していた。

しかし、小保・榎津に変わる新しい河口港として、住吉 (安永 4 年、 1774）・若津（宝暦元年、1751）が計画的に町建てされ、ここで港 の機能が移ることとなる。

近世期の社会構成を知る史料として榎津・若津は「御諸印札棒併

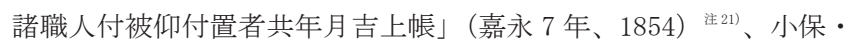
住吉は「蒲池組御小物成盛掛小帳」（安政 4 年、1857） 洋22) がある。

榎津は、木挽き 15 、鍛冶 19、桶師 9、船大工 101、大工 41、穀 物仲買印札 7 、荷米印棒 12 、諸品問屋印札 2 、斗屋問屋印札 1 、代 物小間物店 27、趜印札 13 、造酒印札 6、受酒印札 3、薬種丸散店 印札 3、唐物印札 5、藍瓶印札 7、疊師 4、蓙仲買印棒 6、打綿印棒 21、諸紙仲買印棒 3、小商印棒 3、牛馬直買往来札 13 とある。

若津は船大工 2、穀物仲買印札 5、荷米印棒 11、代物小間物店 13、受酒印札 5 、唐物印札 2、藍瓶印札 1 、打綿印棒 3、牛馬直買往 来札 19、家大工 3、穀物並諸品問屋印札 2、薪問屋印札 1、竹木問 屋印札 1 、油船印札 1 、塩鰞の外諸品問屋印札 1 、茅屋根莫印札 1 とある。

「御諸印札棒併諸職人付被仰付置者共年月書上帳」は若津が開港
してから 103 年経た史料である。榎津は若津が開港することによっ て港の機能が移る。この史料からは榎津の方が繁栄していた様に捉 えられる。若津には久留米藩の米蔵があったことが知られ、「御代々 御軍制之調」洼23) には「享和年間榎津浦船次第に減少」とあり、職 業分布も問屋などが多いことから港の機能が若津へ移っていること は確認できる。しかし、榎津が衰退しなかったのはなぜであろうか。 このことは榎津の職業構成に注目すると理解できる。榎津の印札の 出されている 317 の中で、木工関係の印札が 166 と半数を超えてい る。また、166 中 101 が船大工であることから主に船を製造してい たことが知られる。このことから若津に港が移されても、木工産業 が展開していたため、榎津の繁栄が継続したと考えられる。

小保は、浜問屋 3 、海陸問屋 1 、石炭問屋 $3 、$ 旅人宿 $2 、$ 小店 22 、 造酒屋 2、揚酒屋 $1 、$ 油屋 $7 、$ 糀屋 2、酢奨油屋 2、麦粉小売屋 $3 、$ 菓子屋 3 とある。住吉は、浜問屋 2 、石炭問屋 1 、竹木問屋 $2 、$ 旅 人宿 1 、渡海船宿 1 、小店 10 、揚酒屋 2 、奨油屋 1 、陸問屋 1 とある。 小保は港が移ってからも海陸問屋などがあることから、ある程度 港の機能が残されたと考えられようか。また、小保の別当の吉原家 が住吉の別当を兼衫ること、1851 年から吉原家が大庄屋を務める ことから、小保も住吉に港が移ったからといって衰退はしなかった ようだ。

以上より、小保・榎津は住吉・若津が建設されたにもかかわらず、 小保は蒲池組の政治的中心となる大庄屋を務めたこと、榎津は木工 産業の存在により、安定した社会と空間を保ったと考えられる。ま た、榎津は木工に関わる職種が卓越することが注目されたが、小保 はこれら木工に関する職種は見られず、一般的な在方町とさしてか わらない職種構成で、柳川藩の宿駅に指定されていたこと、境争い が榎津とたびたび起きたことより 注 24$) 、$ 町は隣接するものの、属す る藩によって性格を異にしていたようだ。

\section{2-4. まとめ}

以上、近世後期から近世中期の町並みの展開を平面的に明らかと し、絵図の分析により立体的な復原考察をし、町並みの実相を明ら かとした。また、住吉・若津に港の機能が移ってからも社会構成の 考察により、小保・榎津の繁栄の理由を提示することが出来た。

\section{3. 小保・榎津の町並みの起源}

史料に初めて小保と思われる文字が出てくるのは、管見の限り永 仁 4 年（1296）の「隈文書」 ${ }^{7)}$ で、「小法丸村は三溷郡西郷に属し、 三潴荘鎮守玉垂宮の十朔幣析 5 斗・ 11 月中卯の日祭料米 6 斗の他 5 月 15 日の五月会の際右方相撲人を出し 9 月 19 日の九月会では津村 と 7 番祭頭を勤めそのための料田 2 反があった。」とある。「筑後志」 ${ }^{8)}$ に小保を「ゴボウ」と訓じていることより小法丸は小保であると考 えられる。また、「御船文書」9) (貞和 3 年、1347) には、「祭料米 六斗 十二月朔幣析米 5 斗 九月会 祭頭 相模 迴廟 間 但し 上下ノ小法」とあり、永仁 4 年より若干負担が増大している。上下 の小法とあるように小法丸は上小法・下小法に分かれていたのであ ろう。「立花文書」 ${ }^{10)}$ （文禄 4 年、1595）にも「小保津村」と見える。 近世に港町として成立していること、筑後川河口に面していること から中世にも津（港）の機能を有していたと考えられ、そのため小 保に津を付けていると思われる。

また、小保の地名の由来は二説ある。一つは「旧柳河藩内三㵔郡 
地理歴史考」 ${ }^{11)}$ の津村の地先に又一つの瘤の如き島顕はれたれば 之をコブと呼びしならん」と書かれるコブに求められ、一つは、「大 川の昔と今」 ${ }^{12)}$ の「奈良時代律令制下の五保の制にある」という。

以上、町並夕の起源は 13 世紀後期まで遡ることができようか。

一方、榎津の文献史料の初見は、元亀元年（1570）の「蒲池文書」、 「田尻文書」13) である。その後の中世の文書にも榎津の名は見え、「酒 見文書」 ${ }^{14)}$ (天正 9 年、1581）では「今度以手切出頭、忠儀定無比 類候、仍為其賞、其方居屋敷、蒲池民部少輔跡南分、榎津六町分、 同庄分二ケ所、同人跡永藤四町分、(後略)」とあり、この頃には町 が成立していたと考えられる。「薦野家譜」15) (天正 12 年) には「戸 次遺言・高橋紹運らは上妻郡坂東寺に軍制をまとめ、榎津・酒見城 島辺に放火した」とある。また「天正 13 年にも榎津を攻める」とある。 『北肥戦誌』 ${ }^{16)}$ (天正 12 年）によると、「榎木津の要害に中野式部少 輔清明」「戸次入道遺言・高橋紹運が榎津の在家数百軒を総て焼き 払う」とある。「立花文書」注 25)（文禄 4 年、1595）にも榎津の名が 見える。

また、榎津の地名の由来は三説ある。一つは『太宰管内志 中』 17) の「名義は榎に由有て負せたるべし」と書かれる樹木名のエノキ に求められ、一つは『大川市誌』の「神功皇后が三韓を御遠征にな り、御帰朝の際お船を筑紫の莘原の津にお着けになり津を得たとい われたのが得の津となり、さらに転叱して榎津になったという。」注 26) と書かれる津を得たに求められ、一つは「願蓮寺文書」洋27) の「当 寺開祖善明榎津久米之介と号す。源義明足利十二代将軍之幕下榎津 遠江之舎弟也。（中略）天文五丙申、氏を以て地に命ず」と書かれ る天文 5 年創建の願蓮寺開基榎津久米之助に求められると言う。

小保・榎津ともにこれら以外に町並みの成立起源に結びつく史料 は存在しない。これら諸説を念頭にいれつつ、前節で得られた近世 前期を見通しえる近世中期復原図 (図 10) に投影し、中世に遡る小保・ 榎津の町並みの成立起源について考察を巡らせたい。図 10 を眺め るといくつかの顕著な特徵を指摘できる。

第一は緩やかに曲がる道路に沿って間口・奥行きの不均質な地割 が並ぶ町筋が中心部に位置する本町 ・ 庄分町 ・城町南側 - 長町・水 入町 $\cdot$ 向町南側 $\cdot$ 上町市場 $\cdot$ 中の船津 $\cdot$ 新町と、直線の道路に沿つ て間口・奥行きの均質な地割が並ぶ近世起源の町筋、津村町・薮町・ 向町北側・横町・浦町・城町北側とが明らかに性格を異にする空間 構成を呈する点である。

第二は空間構成上の中心が明確に存在することで、そこから小保・ 榎津の主要な町筋が放射状に広がっている。柳川藩領と久留米藩領 の境に位置し、久留米藩の高札と僅かに離れて柳川藩の高札がおか れ、藩政初期には柳川藩の御茶屋が存在し、都市構造的にも都心と して長らく機能した。また藩境の石がおかれ、その中心としての重 要度も窥える。

第三はこの都心から主要な町筋が川に向かって延びる点で、近世 中期に成立した住吉や若津が川と並行に町筋を設定する点と対照的 である。

第一・二の特質は中世起源の都市に通有し、第三は中世起源の港 町に通有する空間特質であり、これらを手掛かりとして町並みの成 立起源について考察を巡らすことが可能になる。

もう一つの手掛かりは寺院のその場での成立年代である。復原図 に記した成立年代を見ると、中世に成立起源が遡るものは浄福寺の
他、天文 3 年 (1534) の光福寺、天文 5 年の願蓮寺、天文 10 年の 覚了寺、天正 5 年 (1577) の正覚院があり、法泉寺は小保の旧寺地 に天正期（1573 1581）の成立である ${ }^{18)}$ 。城町に置かれたとされ る榎津城 ${ }^{2}{ }^{228}$ は天正 12 年には存在したことが知られる注 299。

さらに町並みの広がる範囲における現状の微地形も参考になる。 これを考察するため、都市計画図の水準点をもとに、高さ $25 \mathrm{~cm}$ お きに等高線を落とし、それを近世中期復原図 (図 10) に再度落とした。 これを中世町場が展開していたと思われる領域に注目して見ていく と、特徵ある四つの地形に明瞭に分けられる。一つ目はこの周辺で 最も高い元法泉寺の $4.75 \mathrm{~m}$ となっている場所（この小高い場所は上 町市場・中の船津・本町・庄分町にまたがる)、二つ目は水入町の 天満神社付近で $4.75 \mathrm{~m}$ と高くなっている場所、三つ目はそれに狭ま れた谷で $4.25 \mathrm{~m}$ のラインが八幡神社から長町・出来町にかけて緩や かに広がっている場所、四つ目は八幡神社西側・新町周辺で急勾配 になっている場所である。注目す心゙き点は八幡神社が水運の良い水 路際、水はけの良いと考える事ができる二つの丘に狭まれた中心に 立地していることである。これらの中心は空間構成上の中心である 札の辻とその南側に位置する小保八幡神社一帯に求められよう。こ の小保八幡神社の創建は元久期（1204～1206）とされ注30)、地名の 初見とおおよそ一致を見る。

以上の検討結果を勘案し、まず、榎津の中世の姿を遡及的に復原 することを試みたい。町境の街路と街路が交わっている場所の角に あたる地割は、角の地割を持つ町の方が先に成立したと考えられる ことから、地割がどちらの町に属しているのかを見る。また、小保 八幡神社の起源が最も古いため、その周辺から町場が形成されたと 考える。そうすると、水入町の後に長町が成立し、長町の後に出来 町が成立し、出来町の後に薮町が成立し、本町、庄分町の後に城町 が成立し、城町、長町の後に向町の南側が成立し、出来町の後に向 町の北側が成立し、横町の後に浦町、船倉が成立したと考えられよ う。さらに、前述の「酒見文書」注31)（天正 9 年）の「榎津六町分、 同庄分二ケ所」の文言にあたる場所を比定してみると、不均質な地 割が並ぶ町筋の榎津城跡のブロックである本町・城町南側・長町・ 向町南側の面積が約 6 町 $\left(5994.6 \mathrm{~m}^{2}\right)$ で、これが榎津 6 町分に相 当寸ると考えられ、庄分は庄分町に当たると考えられ都市形態と古 文書の記述が一致する。

よって、榎津の成立過程は定かではないが、寺院の成立年代や文 献を鑑みると天文期（1532～1555）に起源が求められ、寺院を核 とした多核複合的な空間を形成していたと推察される。天正期には 榎津城が建設され、徐々に本町・城町南側・長町・向町南側・庄分 町を形成したのであろう。水入町は不明であるが、地形が高く、中 心に近いことから、これら諸町と同時期かやや遅れて成立したと予 想される。これらが形成された後、北側へ拡大し、花宗川に沿って 城町北側・横町・浦町・船倉・出来町が形成され、近世の町並夕が 徐々に形成されたと考えられる。

このような榎津が形成される以前に小保の町並みは成立していた と考えられる。中近世移行期の都市史の成果に従えば、「津・泊・ 宿などの水陸交通の要所には、船着場を伴った市町である港町が成 立し、商品を荷揚げする船着場と商品を納める蔵、またはこれらを 管理する港湾管理者の館を頭に頂き、そこから内陸へ向かう街道で 市が開かれ、その両側に商人宿が建ち並び町空間が成立した」注 32) 
と考えられていることから、この水際線に垂直に伸びる道として、 花宗川にある船着場と起源の最も古い小保八幡神社とを結ぶ小保本 通りがこれに該当すると考えられよう。小保八幡神社が位置する字 名が上町市場で、船着場の字名が中の船津とあることは、小保八幡 神社を核として成立した䦕前に、市が開かれたことを想起させ、市 は商品を荷揚げした船着場に向かう一本の道筋上で開かれ、道の両 側には商人を宿泊させた町家が軒を連ね町並みを形成していったと いう仮説が提示できる。小保八幡神社の前面に広場のような空間が 用意されていること、小保の町筋がこの道筋を中心として求心性の 強い空間的なまとまりを有すること、天明 6 年「小保町絵図」(図 8)、 年代不詳「小保町絵図」（図 9) には 9 尺から 2 間の狭小な間口の 地割の見えること、明治期復原図に表れる小保と榎津の境界線が小 保を取り囲むように緩やかに湾曲し、境図（宝暦 9 年）（図 11）に は町別当を務めた吉原家と光楽寺の背面に小保を取り巻く土塁が見 られることが傍証となろう。

\section{結論}

以上、中近世移行期の在方町の空間変容の推定できる福岡県大川 市小保・榎津について考察を行い、以下の点を指摘した。

第一に小保・榎津の都市形態において近世起源の都市形態と中世 起源の都市形態があり、これらの形態が大きく異なることを指摘し た。

第二に小保・榎津の町並夕は近世中期には平入草莫き町家の並 ぶ町並みに所々妻入草莫き町家、妻入瓦莫き土蔵造り町家が点在し ながら町並み景観を構成し、近世後期に町並みが展開を見せ、周辺 部に均質な町並みを形成したことを指摘した。また、小保と榎津は 隣接するものの属する藩によって社会構成を異にすることを指摘し た。

第三に小保・榎津の町並みは小保八幡神社の成立を契機として展 開し、小保八幡神社門前に開かれた市と船着場を起源とし、中世前 期に成立したという仮説を提示した。それらから派生するかたちで 光福寺・願蓮寺・覚了寺の創立を契機とし、町並みの様相を呈して いったものと推察し、その展開は天正期に建設された榎津城建設に ともない、花宗川沿いと久留米に向かう街道筋、柳川に向かう街道 筋に町並みが拡大したことを遡及的に考察し、都市の成立過程の仮 説を提示した。

\section{謝辞}

本稿は修士論文をもとに加筆・修正している。指導していただいた故宮本 雅明先生に哀悼の意と謝意を表したい。

\section{注}

注 1) 多くの先行研究があり代表例をあげると中野茂夫・藤川昌樹・河東 義之「近代における在郷町の都市・建築空間と産業化の影響 - 茨城県兴 川市真壁町を事例として一」日本建築学会計画系論文集 621 号, 2007. 11、 秋元 一秀 - 竹下 輝和「町屋敷地の奥行方向の変容過程からみた内子 町八日市及び六日市の空間構成の特徵」日本建築学会計画系論文集 527 号, 2000.1、黑野 弘靖 - 菊地 成朋「街路と屋敷の対応関係から夕た在郷 町の空間特性：小矢部市「津沢」のケーススタディ」日本建築学会計画 系論文集 509 号, 1998.7 等がある。

注 2）参考文献 1）の他、三浦要一「土佐の在郷町・奈半利の都市空間に関 する研究」日本建築学会中国支部研究報告集 26,2003 にも中近世移行期の 考察が窥える。

注 3）「明治の地籍図」(大川市法務局藏)

注 4)「筑後国三潴郡榎津町土木取調絵図」（明治 11 年）（柳川古文書館蔵）
注 5）「筑後国三濐郡榎津町之図」（明治 11 年以降明治 21 年以内）（柳川古 文書館蔵）

注 6)「筑後国三潴郡小保町土木取調図」(明治 11 年）（柳川古文書館蔵）

注 7）「明治の地籍図」(大川市法務局臟)

注 8)「筑後川絵図」(文政 2 年) (久留米市立図書館蔵)

注 9）「住吉宮旧記写」『吉原文書』(柳川古文書館蔵)

注 10）参考文献 2)

注 11）参考文献 3）所収

注 12）参考文献 4）所収

注 13）参考文献 6）所收

注 14）中世起源と思われる町並みに引き続いていることから奥行きが若津 と異なる寸法になったと考えられ、それに伴い間口も若干広いと考えられ る。

注 15）「三潴郡蒲池与絵図」（正保 2 年）（柳川古文書館蔵）

注 16)「小保町絵図」(天明 6 年)『吉原文書』(柳川古文書館蔵)

注 17)「小保町絵図」(年代不詳、天明 6 年以降))『吉原文書』(柳川古文書館蔵)

注 18）「境図」（宝暦 9 年）『吉原文書』(柳川古文書館蔵)

注 19）参考文献 2)

注 20）参考文献 2)

注 21）「御諸印札棒併諸職人付被仰付置者共年月吉上帳」（嘉永 7 年）『田中 文書』(柳川古文書館蔵)

注 22）「蒲池組御小物成盛掛小帳」(安政四年)『吉原文書』(柳川古文書館蔵)

注 23）「御代々御軍制之調」(享和年間)『田中文書』(柳川古文書館蔵)

注 24）参考文献 2)

注 25）参考文献 11)

注 26）参考文献 2)

注 27)「願蓮寺文書」(願蓮寺蔵)

注 28）「大川市誌」には榎津城の存在地の根拠として城町の名が有ることか らここにあるとされる。今回の地籍図の作成及び分析より、本町、長町、 向町、城町の町屋敷の地尻の関係は互いの地尻は直接に接し合わずその間 には寺院、墓、田、畑等の空隙空間があることを指摘した。この形態的特 徵及び城町という地名よりここに榎津城があった可能性は高い。

注 29）参考文献 16)

注 30）前掲「大川市誌」には「蒲池名所旧跡帳」に「延長年中（923～ 930)、筑前国大宰府天満宮を勧請し氏神にしていたところ、元久年中 （1204～1206）京都の人、秦段蔵（「神社明細帳」には、高倉院の家臣秦 弾政行とある）というものが当地へ来たり、山城国石清水八幡宮を歓請し、 九月十五日入津せしをもって同日を祭日と定む。古来天神の敷地なればと てその節四か所に天満宮を安置し、いまに社あり。外に祇園社もあり。」 とあり、延長年中に天満宮、元久年中に八幡神社が創建されたことがわか る。

注 31）参考文献 14)

注 32）参考文献 1)

\section{参考文献}

1）宮本雅明：都市空間の近世史研究, 中央公論美術出版, 2005

2) 大川市誌編集委員会編 : 大川市誌, 大川市, 1977 年

3) 久留米市史編さん委員会編集 : 久留米市史第 9 巻資料編近世, 久留米 市, 1993 年

4) 福岡県：福岡県史資料第 3 輯, 福岡県, 1934 年

5) 石原為平著 : 石原家記, 1763 年 (1973 年名著復刻版より復刻)

6) 久留米市史編さん委員会編集 : 久留米市史第 8 巻資料編近世, 久留米 市, 1993 年

7）竹内理三編：鎌倉遺文 古文書編 第 25 巻, 19238, 東京堂出版, 1983

8）杉山正仲・小川正格編：筑後志, 本荘知新堂, 1907, p 353

9）瀬野 精一郎編：南北朝遺文 九州編 第 2 巻, 2372, 東京堂出版, 1981

10）福岡県：福岡県史資料第 4 輯, 福岡県, p153, 1933 年

11）渡辺村男編著：柳川藩叢書 第一集（復刻版），青潮社, 1984

12）おおかわ文庫編集委員会：大川の昔と今, 大川市, 1990

13) 東京大学史料編纂所編: 大日本史料第 10 編之 4, 東京大学出会, p342, 1968

14) 東京大学史料編纂所編: 大日本史料第 11 編之 2 , 東京大学出会, p809, 1982

15）九州文化総合研究所太宰府調査文献班編：大宰府太宰府天満宮博多史料 続中世編 6, 九州文化総合研究所, p161, 1960

16）馬渡俊継原著・高野和人編纂：北肥戦誌，青潮社, p706, 1995

17）伊藤常足編録：太宰管内志 中, 歴史図書社, p192, 1969

18）古賀正美解読：寬文十年久留米藩寺院開基, 久留米郷土研究会, 1982 